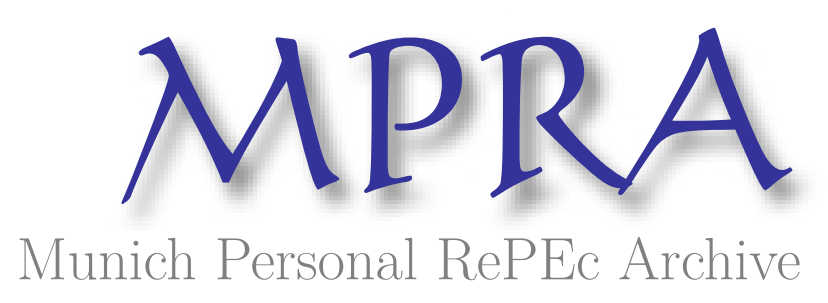

New research methods of business history

Lepore, Amedeo

Mufad

7 February 2012

Online at https://mpra.ub.uni-muenchen.de/36952/

MPRA Paper No. 36952, posted 29 Feb 2012 02:37 UTC 


\title{
New research methods of Business History
}

\author{
Amedeo Lepore - University of Bari
}

\section{Premise}

Business History, while not clearly established or widely recognized, is an open discipline that can include, in addition to the issues related to the evolution of economy, enterprises, market and business world, other institutional, cultural and social areas, related to contemporary implications derived from the long process of industrialization. As stressed by Joseph Schumpeter, an assessment is too often overlooked by more recent studies, History is an essential tool for the study of business and entrepreneurship: «Economic historians and economic theorists can make an interesting and socially valuable journey together, if they will. It would be an investigation into the sadly neglected area of economic change» (J. Schumpeter, The Creative Response in Economic History, in "The

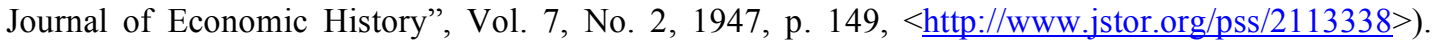
According to the approach of this article, the extensive use of historical methodology (i.e., that comparative) is a fundamental element for the analysis of the company, the entrepreneurship and its dynamics. It is the nature of entrepreneurship - in relation to the uncertainty of the definition of the preparatory phase of the business, the long-term perspective of its activities and the diversification of its character from place to place, as well as over time - that underscores the vital importance of a historical vision for the study of the company and its operation within the capitalist system.

The first industrial revolution started at the end of the eighteenth century, followed by a profound industrial transformation that took place in the second half of the nineteenth century, the mass industrialization of the twentieth century and the new post-Fordist scenario of the twenty-first century are the historical milestones of a phenomenon that has accompanied the various stages of development and the world economy over the period characterized by the supremacy of the capitalist production. During this long period, the business has passed the initial and then more extensive system of factory, located in large urban centers and related to traditional areas of production; to an increasingly complex structural configuration within which have emerged, thanks to new forms of State intervention, the metallurgical, mechanical, chemical and electrical areas, along with a first sea change of media, transportation and marketing of goods and services; to a large growth of production capacity, with the emergence of mass markets and "big business" in the United States of America and their subsequent deployment in Europe, in the era of golden age; the more profound change in capitalism, promoted by more recent process of globalization and the revolution of ICT, with the formation of a new economy and, especially, with the progressive shift towards a multitude of niche markets, that has characterized the new dimensional change of the so-called "fourth capitalism" (see F. Amatori, La storia d'impresa come professione, Venezia: Marsilio Editori, 2008). That said, you cannot deny that remarkable events occurred also in the past ages and that valued areas and facilities already existed at that times, but we want to point out the core focus for the growth of this discipline was represented by the development of the capitalist system within industry, agriculture, services, accounting and finance. In short, Business History is an essential element in terms of quality for understanding the economic structure of a country from a dynamic and comparative point of view. In this context, as Alfred Chandler stated: "The historian has at least two exacting and exciting challenges. One is that of relating specific human events and actions to the ever-changing broader economic, social, political and cultural environment. A second is the development of generalizations and concepts which, although derived from events and actions that occur at a specific time and place, are applicable to other times and places, and are, therefore, valuable as guideposts for or as tools of analysis by other historians as well as economists, sociologists, anthropologists and other scholars. They may even be of interest to the informed general public and of some use to actors in contemporary political, social or cultural dramas. But before such challenges can be met, data are needed. The first step must be detailed description of the actors and their actions; and for business history that means, of course, of businessmen and businesswomen and the enterprises they managed. If descriptions are carefully related to the larger scene, then the second challenge can be taken up. 
Only after the accumulation of a multitude of case-studies can generalizations and concepts which are not tied to a specific time and place be induced» (A. D. Chandler jr., Comparative Business History, in D. C. Coleman, P. Mathias (ed.), Entreprise and History. Essays in honour of Charles Wilson, Cambridge: $\quad$ Cambridge University $\quad$ Press, $1984, \quad$ p. 3,

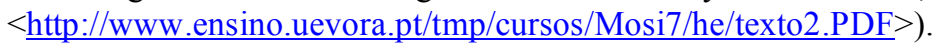

\section{The origins and development of the discipline}

Not surprisingly, early in the twentieth century Business History sprang out from the United States in relation to the "big business" model, as an analysis and in-depth examination activity, even of a critical aspect, addressed to some kinds of development and business strategies. As written by Alfred D. Chandler: «Business history appeared first as a distinguishable sub-field of economic history in the late 1920s and the 1930s. Its parent, economic history, became an identifiable discipline only a few years earlier. In the United States, and in Britain too, economic history was rooted more in the discipline of history than in that of economics. Economists interested in institutional change did write impressive historical studies» (A. D. Chandler jr., Comparative Business History, cit., p. 4, $<$ http://www.ensino.uevora.pt/tmp/cursos/Mosi7/he/texto2.PDF $>$ ). One of the two founders of the discipline, Edwin F. Gay, started from a background closely related to Economic History and thought that Business History should provide the elements essential to an understanding of the processes of economic development. It's in this particular scenario, however, that the first examples of Business Schools appeared: they were conceived as centers for study and training in the disciplines related to business management, such as Management and Marketing. The first Chair of Business History (Isidor Straus Chair) was established in 1927 at the Harvard Business School, and was covered until the middle of last century by Norman S. B. Gras, the other founder of Business History, a scholar prone - unlike Gay, which also had been a pupil - to the use of a methodology of inductive and developmental analysis of specific business cases. According to his approach, the discipline is based on processing, albeit in pioneering form, of biographies of entrepreneurs and businesses stories through the use of corporate or personal documents: only after gathering and evualting a large mass of case studies by scholars would be possible to develop theoretical generalizations. However, the orientation of Gras, who used to divide Business History in six different periods - "Pre-business capitalism", "Petty capitalism", "Mercantile capitalism", "Industrial capitalism", "Financial capitalism" and "National capitalism" (see N. S. B. Gras, Business and Capitalism: An Introduction to Business History, New York (NY): F. S. Crofts, 1939, $<$ http://www.beardbooks.com/beardbooks/business_and_capitalism.html $>$ ) -, has contributed, thanks to his traditional approach, to maintain the discipline in a state of isolation, even compared to the other social sciences. That approach was driven, in Britain in the early fifties of last century, by Charles Wilson, whose case histories, combined with those of Gras, continued for a long time being a source of fundamental knowledge for Business History.

After World War II, Joseph Schumpeter, as an inspirer, and Arthur H. Cole, as a guide, founded the Center for Research in Entrepreneurial History, where scholars like Alfred D. Chandler, Thomas Cochran and David Landes were trained. They were involved in the analysis of entrepreneurship, the relationships between business and society, the role of innovation, the relationships between strategy and structure, and the creation of the organizations. In this way, they turned the page, by going far beyond the simple analysis of case studies and closer to the social sciences, particularly sociology, starting from the evolution of the discipline overseas: «Our post-war generation could have learned much from observing how Commons's concepts of legal rights and of economic transactions permitted him to generalize about economic processes and how Mitchell and later Schumpeter used their massive data to generalize about the dynamics of business cycles. In the late 1940s, however, the institutionalists were out of favour among economists. The driving edge of their discipline was in the new Keynesian macroeconomic analyses and the new mathematical techniques of econometrics. Historians dealing with complex human actions found both the new approaches and the methods of the economists difficult to apply. Too often such quantitative techniques demanded the isolation of a relatively small number of quantifiable variables, an isolation which distorted the reality of the situation under analysis. In micro-economics, for example, the 
business enterprise continued to be defined primarily as a unit of production (that is, a factory), one that responded dutifully to the motive of profit maximization, rather than as a complex human organization that co-ordinated productions with distribution, finance and changing technology. The theory of the firm remained a theory of production. And in econometrics, individuals - their thought and action - simply disappeared from the scene. On the other hand, in the late 1940s other social sciences, particularly sociology, had much to offer younger historians seeking to do something with their case-studies. In sociology the thought and action of individuals still remained at the centre of analysis. In observing men and women at work at play, sociologists had generated valuable ideas about the structure and process of human organizations and action. They had demonstrated that such generalizations, typologies and concepts need not be tied to a specific time, place or culture» (A. D. Chandler jr., Comparative Business History, cit., p. 8 ,

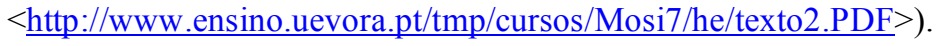

The change, which focused on institutional processes, as well as the structures and functions, promoting a kind of a "new institutionalism", has encouraged the inclusion of specific case studies into a broader historical perspective, based on the evolution of the context in which the company operated, and, at the same time, gave impetus to the dissemination of new theoretical generalizations, which reflected the influence of other disciplines. The novelty of this approach, which retained the types and the usual sources, was the adoption of a comparative method, able to examine and compare the stories of a variety of institutional actors, entrepreneurs and businesses. The engine of this investigations was represented by larger companies, which exactly in the United States had emerged and were widely disseminated, becoming the main feature of that system. A recent publication (see D. S. Landes, J. Mokyr, W. J. Baumol (eds.), The Invention of Enterprise: Entrepreneurship from Ancient Mesopotamia to Modern Times, Princeton (NJ): Princeton

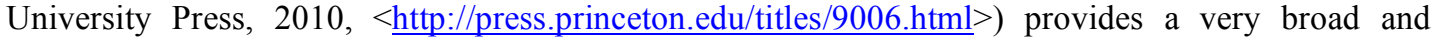
significant fresco of Entrepreneurial History, with particular reference to its development in advanced countries. In addition, a framework for synthesis of evolution of matter from the theoretical point of view is offered by the following scheme.

Figure 1. Timeline of History of Entrepreneurial Thought

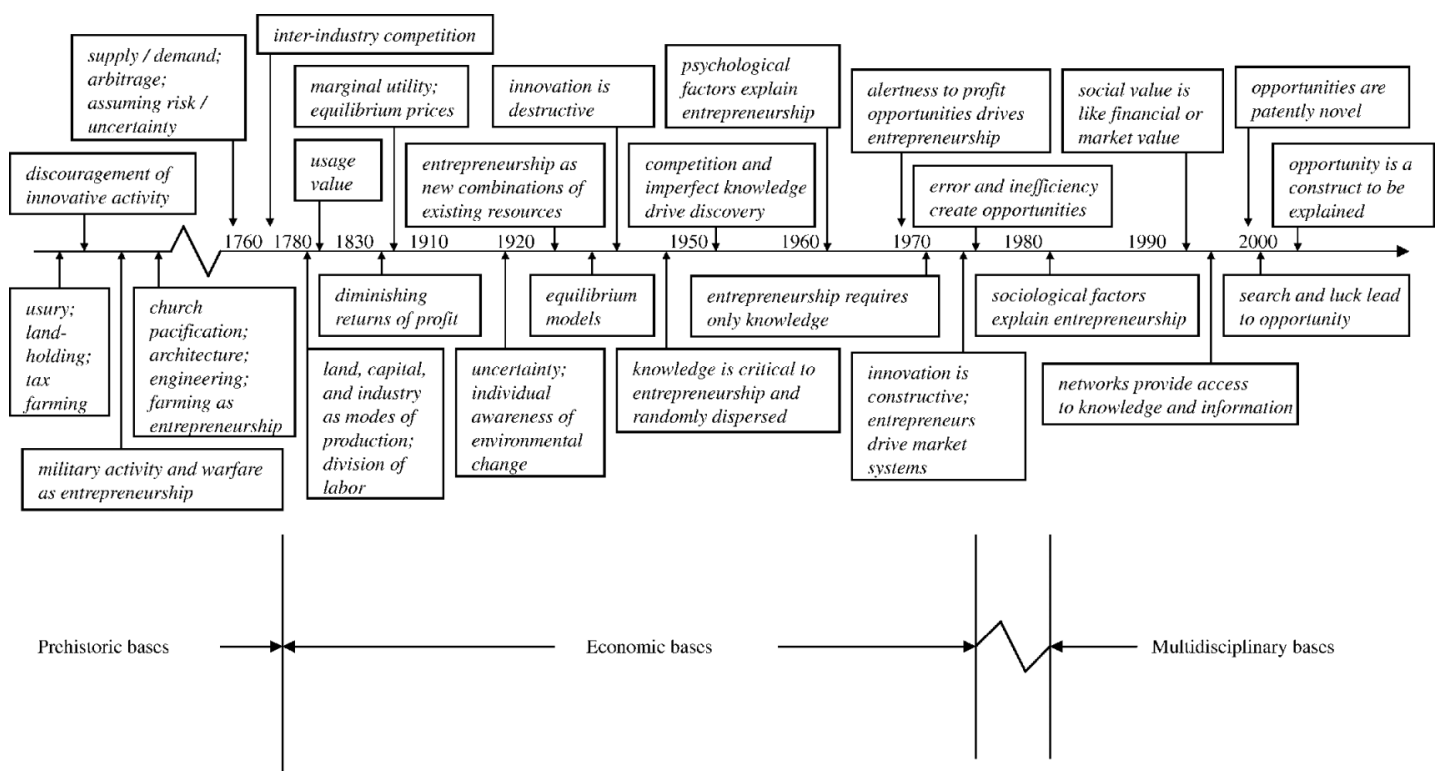

Source: P. J. Murphy, J. Liao, H. P. Welsch, A conceptual history of entrepreneurial thought, in "Journal of Management History", Vol. 12, No. 1, 2006, $\quad$ pp. $\quad 12-35$, <http://www.emeraldinsight.com/journals.htm?articleid=1537775\&show=html $>$. 
But with the work of Alfred Chandler on Strategy and Structure (see A. D. Chandler jr., Strategy and Structure: Chapters in the History of the Industrial Enterprise, Cambridge (MA): MIT Press, 1962, < http://www.beardbooks.com/beardbooks/strategy and structure.html $>$ ) the study of business experiences was linked to the principles of organizational innovation and to the economic theory, adopting a different model than the centralized and functionalist U-form, such as the managerial, decentralized and multidivisional M-form. Moreover, the vision of the crucial importance of the large managerial enterprise, developed, notably, in the work on the Visible Hand (see A. D. Chandler jr., The Visible Hand: The Managerial Revolution in American Business, Cambridge (MA):

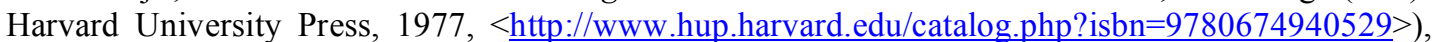
has been another milestone of the discipline, which has dominated the American research scene in Business History until the eighties of last century. As has been pointed out, about Chandler: «Unquestionably he was the scholar who gave an academic and scientific consistency to business history. In 1997, Richard John (...) half seriously wrote that, in business history circles, $B C$ means "Before Chandler". Indeed, before Chandler, business history was an isolated discipline, totally unconsidered by historians and by economists (...). Thanks to Chandler's methodology (with its sharp focus on the entrepreneurial actions that gave birth to big business and a wide comparison with research on hundreds of companies) it was possible to make generalizations that were indispensable reference points not only for business historians but also for scholars in other disciplines» (F. Amatori, Busines History: State of the Art and Controversies, in "Revista de Historia Industrial", No. 39, XVIII, $2009, \quad$ p. 18 , $<$ http://www.raco.cat/index.php/HistoriaIndustrial/article/viewFile/142797/194366>).

The criticism, particularly by scholars such as Charles Sabel and Jonathan Zeitlin, has focused the setting of Chandler which made a distinction between businesses and the context in which they acted, as well as his choice to maintain a strict division between different periods of evolution of matter. Over the last thirty years, during what was called the post-Chandlerian era, has increased the use of new tools, such as those offered by agency theory of Michael C. Jensen and William H. Meckling and economic theory of transaction costs of Oliver E. Williamson, who took over the previous analysis of Ronald Coase. In this context, it is considered that during the nineties of last century, with the advance of the managerial enterprise to more specialized and less vertically integrated forms of business, the Chandlerian paradigm has lost strength and was gradually replaced by the interest for a new type of Business History "economically informed". The new paradigm of Business History has had to steer toward the great changes taking place in recent decades, which have affected the process of globalization, relations between business, society and culture, entrepreneurship and analysis of business networks.

The phenomenon of globalization has given impetus to an expanded dimension, on an international level, of companies, as an expression of the growing weight of emerging countries like China, India and Brazil, more than the great divergence between the West advanced countries and the rest of the planet. The relationship between business and society, a field of investigation undeveloped until some time ago - also in terms of "economic performance of business", as well as of impact with the environment and public policies - has acquired new importance in scope of Business History more recently, with significant space dedicated to the growth from the bottom of the combination of technology and culture. The field of entrepreneurship has come to the fore in the last two decades, becoming the hallmark of an original research, despite the complexity of conceptualization: «Entrepreneurship is a topic that has dominated public debate in recent twenty years and that (...) has acquired a legitimacy that previously was far from possessing (...). Today the term "entrepreneur" has certainly taken the most positive characters in the collective imagination, yet entrepreneurship is an elusive concept, difficult to define, a protean concept, virtually impossible to channel in a formalization» (F. Amatori, Tipologie imprenditoriali nella storia dell'Italia industriale: una rivisitazione, in F. Amatori, A. Colli (eds.), Imprenditorialità e sviluppo economico. Il caso italiano (secc. XIII-XX), Milano: Egea, 2009, pp. 9-10, <http://www.egeaonline.it/PDF/226a479e-55ef-4ec08966-cbe8a1707a8d.aspx >; see G. Berta, L'imprenditore. Un enigma tra economia e storia, Venezia: Marsilio, 2004). Nevertheless, scholars have identified a way forward: "The historical study of entrepreneurship has been particularly concerned with understanding the process of structural change and development within economies. Business historians have focused on understanding the underlying character and causes of the historical transformation of businesses, industries and 
economies. This historical research has typically employed a Schumpeterian definition of entrepreneurship. Unlike the recent management scholarship, it has not focused primarily on new firm formation, but rather on the varying forms that innovative activity has taken and on the role of innovative entrepreneurship in driving changes in the historical context of business, industry, and the economy» (G. Jones, R. D. Wadhwani, Entrepreneurship and Business History: Renewing the Research Agenda, Boston (MA): Harvard Business School, Working Papers Collection, 2006, pp. 3-4, $<$ www.hbs.edu/research/pdf/07-007.pdf $>$ ). Reality growing number of "network corporations", finally, led to the spread of the new $\mathrm{N}$-form model, which focuses the deverticalisation and flattening of hierarchical levels, through a growing porosity of business structures. These changes, together with other summarized in the box below, contributed to the evolution of the business theories.

Figure 2. Changes in theories on the enterprise

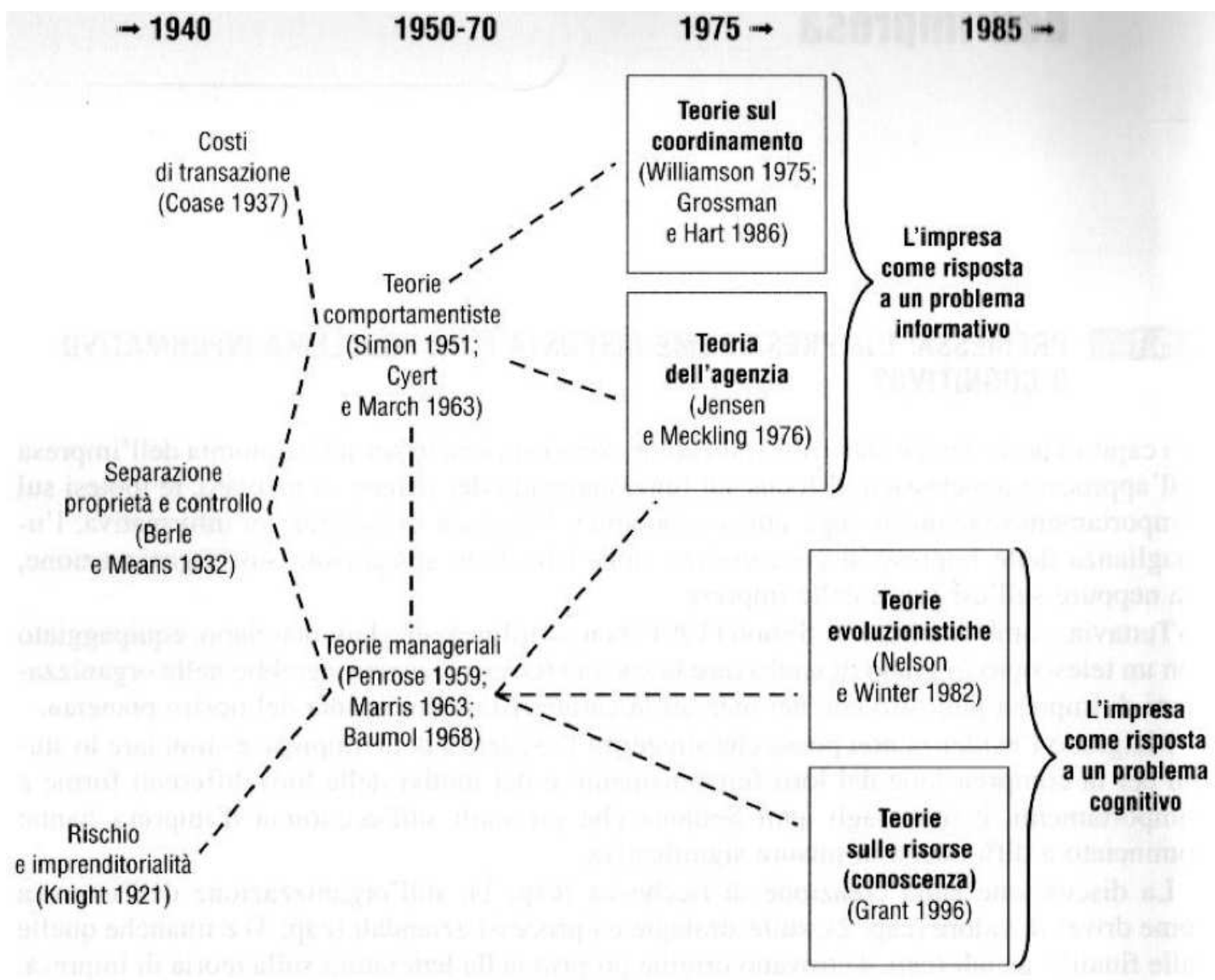

Source: Theories on the enterprise, Materials, $<\underline{\mathrm{http}} / / / \mathrm{www} . \mathrm{cstassisi.eu/public/upload/Teorie} \mathrm{sull} \mathrm{impresa.pdf}>$.

Anyway, the American experience served as a pacesetter in many other countries, where Business History had known a large diffusion from the second half of last century. In Britain, however, the evolution of the discipline has been linked to the idea that it had not substantial autonomy. Indeed, as argued by Peter L. Payne: «in Great Britain, business history - despite substantial developments in recent years - is still regarded as an integral part of economic history» and «most of those who find their source material primarily in company records and who take as their starting point the entrepreneur and the firm rather than anything else (...), tend to see themselves as economic historians and, like historians everywhere» (P. L. Payne, British Busines History: A Personal Survey, in "Business and Economic History", Vol. 7, 1978, pp. 90-91, <http://www2.hnet.msu.edu/ business/bhcweb/publications/BEHprint/v007/p0090-p0098.pdf >, $\quad<$ http://www.hnet.org/ business/bhcweb/publications/BEHprint/v007/p0090-p0098.pdf $>$ ). On the contrary, in Japan 
this discipline, with its large number of scholars, has gradually taken a greater importance as compared to the Economic History itself, as was pointed out by Franco Amatori and Geoffrey Jones, in an analysis dedicated to progress of the theme of "history of business enterprise and business systems" in recent decades (see F. Amatori, G. Jones, Business History around the World, Cambridge: Cambridge University Press, 2003). In this regard, should be highlighted the strong autonomy of the History of Japanese firm, noting that: «Keiichiro Nakagawa, the scholar behind the formation of the Business History Society of Japan in 1965, envisioned that the new association would foster dialogue between business and economic historians. In practice, however, participants adopted the methods and approaches of those U.S. business historians who had distanced themselves from economic history» (N. R. Lamoreaux, D. M. G. Raff, P. Temin, Economic Theory and Business History, 2006, p. 9, $<\underline{\text { http://www.international.ucla.edu/economichistory/naomipage/lrt, } \% 20 \text { bus } \% 20 \text { hist, } \% 202 \% 20 \text { aug } \% 2}$ 02006.pdf $>$, now in G. Jones, J. Zeitlin (eds.), The Oxford Handbook of Business History, New YorkOxford (NY): Oxford University Press, 2008). In Germany, according to tradition, the discipline has developed in the form of company history or entrepreneurial biography, or in a combination of these two disciplines. As noted: «business historians had mainly came out of political and social history, and they worked to make Chandler's paradigm less abstract_-for example, by opening up the "black box" of management and examining the social origins, training, and methods of operation of the professionals who staffed company hierarchies, as well as the role played by large German banks in financing and directing major enterprises (...). They were also preoccupied - understandably given Germany's twentieth-century history-with the relationship between business and the state» (N. R. Lamoreaux, D. M. G. Raff, P. Temin, Economic Theory and Business History, cit., pp. 8-9, $<$ http://www.international.ucla.edu/economichistory/naomipage/lrt, $\% 20$ bus $\% 20$ hist, $\% 202 \% 20$ aug $\% 2$ 02006.pdf $>$ ). In France, Spain and Scandinavia, business history has assumed the role of university education during the eighties of the past century, giving a strong impulse to the research activity. In Italy, this discipline has been taught in the universities since the last decades, following the American example, yet developing as well in the History of Industry, Labor History and History of Economic Institutions: this growth has in any case, taking into account the peculiarity of the dimensional structure of production in Europe and Italy, in particular, characterized by a form of "fourth capitalism" (see G. Turani, I sogni del grande Nord, Bologna: il Mulino, 1996; A. Colli, Il quarto capitalismo, Venezia: Marsilio, 2002), who took office after the phases of pre-eminence of ensembles of the public and private large enterprise and after the period of ascent of the scheme of the districts and small companies, not finding a similar consideration in the American experience. Yet, despite its undoubted success in many international and national realities, it should be noted that in several other countries, this discipline is still at an early stage of growth. Just as it highlighted the diversity of the American model of enterprise than continental: while, in the United States, has established an analytical approach, based on the enterprise considered as an object, "which is a good or a set of assets, to be put on the market» (P. A. Toninelli, Storia d'impresa, Bologna: il Mulino, 2006, pp. 61$62)$; in Europe, has preferred a concept based on the entrepreneur, i.e., on the identification of the «enterprise with a person, or a group of people (family), or a community (district), or an activity that will generate jobs and wealth for its referents» (P. A. Toninelli, Storia d'impresa, cit., p. 61). This significant difference also provides an interpretation of distinct events and of the evolution of Business History on both sides of the Atlantic.

After this limited excursion, you may agree with what Franco Amatori said, taking stock of the current state of Business History: «at present business history seems to be in very good health. I haven't done precise quantitative inquiries but we all know that business history has three major journals with a global diffusion (Business History Review, Business History, and Enterprise and Society). Additionally, another important journal (Economic History Review) is increasingly inclined to accept contributions focusing on business history. Furthermore, each of Europe's major nations as well as Japan has at least one publication dedicated exclusively to this field of studies. There are also important associations such as the BHC (Business History Conference, a US-based initiative) and EBHA (the European Business History Association). In addition here in Europe there are several associations at a national level (...). Overall, business history seems to be one of the liveliest areas of economic history. I think that this is happening:

- because in our discipline human beings — individually or collectively — never disappear; they are always at the center of the stage 
- because the enterprise - that is our major unit of analysis - can be tackled or observed under an almost infinite number of variables

- and, finally, because business history (with its capacity to often link micro and macro) gives an important contribution to understanding the evolution of national and international economic development» (F. Amatori, Busines History: State of the Art and Controversies, cit., p. 17, $<$ http://www.raco.cat/index.php/HistoriaIndustrial/article/viewFile/142797/194366>).

\section{Object of the discipline and traditional methods of study}

Business History deals, primarily, with large enterprises and, through a careful evaluation, can trace not only corporate events, but fundamental issues pertaining to the industry and the general context in which they operate. The corporation, in fact, while performing its activities in the goods and services market, i.e., the circuit of production and distribution, is a complex business organization, which has acquired increasing importance and role in society and in collective action every day and, therefore, has exceeded the boundaries of its original scope. However, in many realities, particularly in Italy, the analysis takes into consideration the evolution of a different system, based on midsize, small and micro enterprises, perfectly in line with the expansion of the niche market. The Italian productive structure occurred, since the postwar period, with original features, as highlighted by some studies, which, in the seventies: «emphasized the so-called organizational forms with high degree of regionalization, not connected to big business, in the reaction of Italian economy to exogenous shocks, to the stiffness of the large firm in the face of market and technology changes. The analysis of "clusters" of Marshallian ancestry promoted by Becattini and the Third Italy started by Bagnasco can also be found in the historiographical side with the initiation of studies on so-called "historical alternatives to the mass production" conducted by Charles Sabel and Jonathan Zeitlin» (G. Piluso, A. Calzolari, R. Mancino, Gli archivi delle imprese industriali, in Storia d'Italia nel secolo ventesimo. Strumenti e fonti, edited by C. Pavone, vol. III, Le fonti documentarie, Roma: Ministero per i Beni e le Attività Culturali, Dipartimento per i Beni Archivistici e Librari, Direzione Generale per gli Archivi, 2006, p. 557, <www.archivi.beniculturali.it/DGA-free/Saggi/Saggi 88.pdf>; see G. Becattini (ed.), Mercato e forze locali: il distretto industriale, Bologna: il Mulino, 1987; A. Bagnasco, Tre Italie. La problematica territoriale dello sviluppo italiano, Bologna: il Mulino, 1977; C. F. Sabel, J. Zeitlin, Historical Alternatives to Mass Production: Politics, Markets and Technology in Nineteenth-Century Industrialization, in "Past and Present", No. 108, 1985, $<$ http://mfs.uchicago.edu/upcoming/capitalisms/readings/Sabel.pdf $>$ ). In the case of groups and medium-sized enterprises, then, was recently considered that typical trend, characterized «by a progressive transformation of our industry driven by global competition and declining trends of the major national groups» (Il quarto capitalismo, $<$ http://www.mbres.it/ita/mb_pubblicazioni/faq quarto.htm $>$ ), which has become the subject of a major initiative of Mediobanca, that can provide sources and processings of great interest on the matter (see R\&S-Mediobanca per il quarto capitalismo, $<$ http://www.mbres.it/ita/res_pubblicazioni/quarto_capitalismo.htm $>$ ) and an extensive collection of «economic and financial information useful for a non-superficial knowledge of the major Italian groups» (Annuario R\&S, $\quad$ http://www.mbres.it/ita/res_pubblicazioni/annuario.htm>; cfr. shop.mbres.it, $\quad<\underline{\text { http://shop.mbres.it/>, }} \quad<\underline{\text { http://shop.mbres.it/cgi- }}$ bin/CalepinoOnLine.storefront/4c77f1e605d1b220274051766faa070d/ChangeLanguage/EN>

$<\underline{\text { http://shop.mbres.it/cgi-bin/calepinoonline.storefront/IT }>,} \quad<\underline{\text { http://shop.mbres.it/cgi- }}$ bin/CalepinoOnLine.storefront/4c77f13405ccf618274051766faa06d7/ChangeLanguage/FR). This broad availability of resources of all kinds on the evolution of firms «of the intermediate size band in the Italian economic system» (R\&S-Mediobanca per il quarto capitalismo, $<$ http://www.mbres.it/ita/res_pubblicazioni/quarto_capitalismo.htm $>$ ), but also «on the average manufacturing firm in major European countries» (Medie imprese europee, $<$ http://www.mbres.it/ita/res_pubblicazioni/medie imprese europee.htm $>$ ), stands in a field of study linked to traditional methods of analysis and to new directions and approaches, that arose in relation to the phenomenon of Italian capitalism - the formation of a plant of medium-sized enterprises, 
belonging to traditional sectors and with offer specialized, able to compete successfully at International level - developed during the nineties of last century.

Business History, generally, shows corporate organizational problems and, consequently, the degree of modernization of firms, but also issues of entrepreneurial character and related dynamic, of substantial importance for the analysis of the economic development of each country. Finally, the discipline studies the cases of the leading companies for each territory, giving the chance to discover its path and process of internationalization. In summary, Business History represents an independent form of research, can enhance the quantitative reconstruction of Economic History, with valuable qualitative informations, in a context not limited to issues of microeconomic framework. One of the starting points for research in Business History is fixed in relation to a primary orientation, faced to: the diffusion of technological innovation (of process, product, distribution and organizational), its coordination, its efficiency and effectiveness (based on business strategy); the examination of entrepreneur's personal characteristics (the family, training, motivation and relationship networks); the identification of the origin of capital (both as growth and diversification of the activities above, than as bank loans, support or patronage). Another reference to the initiation of studies in Business History is the organizational evolution, both in terms of the institutional context, within which business decisions are taken regarding the allocation of corporate resources, both from the side of changing conditions in which decisions are taken and alternatives evaluated one for the purposes of each company. Another starting point of the analysis is the managerial enterprise, which is subject to a coordination unit and a centralized planning of the strategic objectives, as well as for formal organization and a constant flow of information regarding costs, finance and production company. The company does not simply represent an activity aimed at the production and/or exchange of goods and services, but is also an associative structure, of great importance for social and economic organization, since the interaction between people who are part of it favors the creation of new wealth, that can spill over a wide range of players: in this way, the company acquires a value entirely unprecedented, beyond the dimension of "selfish" of the exclusive advantage of privatization and assuming the function of an interpretative model, or, rather, a "historical paradigm" of contemporary reality (see G. Roverato, L'impresa come paradigma storico. Profilo di storia d'impresa, Padova: Edizioni Libreria Rinoceronte, 2010).

The possibility to use corporate archives in a systematic way has started to become effective in Germany as from 1906, when the Rheinisch-Westphälische Archiv (see Stiftung RheinischWestfälisches Wirtschaftsarchiv $\quad z u \quad K o ̈ l n, \quad<$ http://www.ahfmuenchen.de/Mitglieder/Institutionen/StiftRheinWestfWirtArchKoeln.shtml>; Industrie- und Handelskammer zu Köln : : Rheinisch-Westfälisches Wirtschaftsarchiv, <http://www.ihkkoeln.de/Rheinisch Westfaelisches Wirtschaftsarchiv.AxCMS >; Wirtschaftsarchive, $<$ http://www.uni-

konstanz.de/FuF/Philo/Geschichte/Tutorium/Fachebene/Wirtschaftsarchive/wirtschaftsarchive.html >), the first institution for the collection and preservation of the archives of industrial enterprises, was established. This has become a point of reference for the opening of similar institutions in the United States, Holland and Switzerland, even before the Great War, as happened in Britain, France and Sweden, during a later stage. However, as noticed by Maurice Hamon and Félix Torres, it happens that the company is not always capable to preserve its historical sources and, at the same time, the same historical sources are unable to justify, by themselves, the survival of the company (see M. Hamon, F. Torres (eds.), Mémoire d'avenir. L'histoire dans l'entreprise, Paris: Economica, 1987).

Generally speaking, sources for Business History can be divided in four different types: those generated by the company itself, classified into primary and secondary; those originated outside the enterprise, for example, public institutions, trade unions and associations; oral sources, as shown by Renato Covino, in the book dedicated to new sources for the historiography of enterprise and to the increasing use of oral testimony, in a dimension of the company seen not only as an essential element of economic events, but also as a field of relationships, cultures and sensitivities, hard to find in the traditional documentary sources (R. Covino (eds.), Fonti orali e storia d'impresa, Soveria Mannelli: Rubbettino, 2000). Considering the situation from a different point of view, there are also: public sources, which may be published or unpublished; private sources, which are based on company archives, but also on stories "by word of mouth", based on memoirs, on letters from enterpreneurs and on other findings; finally, other sources, represented by the archives of entrepreneurial associations 
and trade unions. The traditional methodology of research in business history focuses on the use of major sources, represented, above all, by business archives. The types of documents contained in these deposits of corporate memory can be divided into several key divisions: social or corporate records (memorandum and articles of incorporation; the shareholders' register; minute-books of the corporate bodies); accounting and administrative documents (correspondence, contracts and other practices; documents concerning the personnel, such as rules, employee records, roles of salaries and books freshman; acts of accounting, such as budgets, ledgers, log books, inventory books, cash books, notes, orders and invoices sent); technical documents and design (drawings, process and projects; patents and licenses; tables, charts, plans and layouts; photos and videos; exhibits of machinery and equipment; samples and finished products). The table below shows, in a nutshell, the different types of resources for Business History, rightly pointing out the primary sources, namely, the official documentation, which provides those elements essential for the reconstruction of the historical features of the company, as well as, of course, the secondary sources produced by the company itself, sources produced outside it and oral sources.

Table 1. Types of sources for Business History

\begin{tabular}{|c|c|c|c|}
\hline \multirow[t]{2}{*}{ Typology } & \multirow[t]{2}{*}{ Source } & \multicolumn{2}{|c|}{ Current location } \\
\hline & & If the firm is active & If the company ceases \\
\hline \multirow{7}{*}{$\begin{array}{l}\text { Primary } \\
\text { sources } \\
\text { produced by } \\
\text { the enterprise } \\
\text { (social books } \\
\text { and like) }\end{array}$} & Constitution Act & Firm/Notary/Accountant & Chamber of Commerce \\
\hline & Statute & Firm/Notary/Accountant & Chamber of Commerce \\
\hline & Other deeds & Firm/Notary/Accountant & Chamber of Commerce \\
\hline & Minutes of the Board & Firm/Notary/Accountant & Liquidators/Court \\
\hline & Minutes of meetings & Firm/Notary/Accountant & Liquidators/Court \\
\hline & Other social books & Firm/Notary/Accountant & Liquidators/Court/B.u.s.a.* \\
\hline & $\begin{array}{l}\text { Financial Statements } \\
\text { and Annexes }\end{array}$ & Firm/Accountant & Liquidators/Court/B.u.s.a.* \\
\hline \multirow{8}{*}{$\begin{array}{l}\text { Secpondary } \\
\text { sources } \\
\text { produced by } \\
\text { the enterprise }\end{array}$} & Correspondence & Firm & \\
\hline & House organs & Firm/Stakeholders & \\
\hline & Patents and similar & Firm /Consultants & Patent office \\
\hline & Technical reports & Firm & \\
\hline & Other gray literature & Firm & \\
\hline & Advertising materials & Firm & \\
\hline & Materials $C S R$ & Firm & \\
\hline & Pictures & Firm & \\
\hline \multirow{6}{*}{$\begin{array}{l}\text { Sources } \\
\text { produced } \\
\text { outside the } \\
\text { enterprise }\end{array}$} & Materials associations & Association & Association \\
\hline & Materials union & Unions & Unions \\
\hline & Materials of public & Ministries/State Archives & Ministries/State Archives \\
\hline & Printed sources & Print & Print \\
\hline & Magazines & Magazines & Magazines \\
\hline & Pictures & Owner photo & Owner photo \\
\hline \multirow[t]{5}{*}{ Oral sources } & $\begin{array}{l}\text { Testimonials } \\
\text { entrepreneurs }\end{array}$ & Firm/Archives/Local Libraries & Archives/Local Libraries \\
\hline & $\begin{array}{l}\text { Testimonials } \\
\text { leaders }\end{array}$ & Firm/Archives/Local Libraries & Archives/Local Libraries \\
\hline & Stories of employees & Firm/Archives/Local Libraries & Archives/Local Libraries \\
\hline & $\begin{array}{l}\text { Testimonials } \\
\text { stakeholders }\end{array}$ & Firm/Archives/Local Libraries & Archives/Local Libraries \\
\hline & More testimonials & Association & Archives/Local Libraries \\
\hline
\end{tabular}

\footnotetext{
* B.u.s.a. $=$ Bollettino ufficiale delle società per azioni.

Source: T. Menzani, Chi conserva e cosa conservare per la storia d'impresa,

$<$ http://www.fondazionetelecomitalia.it/doc/programma/Menzani.pdf $>$.
} 
About these documentary sources, it is necessary to draw the instruction given by Fabio Del Giudice, claiming that: «At present, we don't have a concise definition of the term business archives. The traditional definitions of archive are always useful: i.e. a collection of documents, especially regarding an institution -whether recorded on paper, electronic/digital media, photographs, film etc. An archive may be created by (or acquired from) a single individual or a legal party i.e. families, companies, government bodies or public corporations during their active life. Archives develop spontaneously as a sort of documentary sedimentation of an entity's practical, administrative and juridical activity. All documents in an archives are connected to one another by an original, necessary and defining link. (Lodolini, Carucci). Over the last few years, following the most recent studies of several authors (Carucci, Paletta, Bonfiglio-Dosio), the concept of business archives has broadened, to describe a growing number of them with the term "economic archives". Customarily, the term "business archives" refers to only the documents produced by private entities defined as "business". In contrast, the expression "economic archives" includes those subjects who are both public and private and operate, not only to produce something, but to support, direct and supervise those productive activities as well» (F. Del Giudice, Business archives in Italy: an overview, in "Culture e impresa", No. 3, 2006, p. 1, <http://www.cultureimpresa.it/03-2006/english/atti06-en.html $>$, $<$ http://www.cultureimpresa.it/03-2006/italian/atti06.html $>$, now, with the title Overview of business archives in countries around the world: Italy, also in International Council on Archives, 2006,

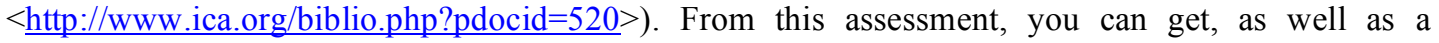
guidance for the use of more established tools for research in Business History, also the specific indication of the level and importance, for scholars, of a methodology able to exploit these resources in the most efficient and valuable way in order to get the targets of investigation. In any case, traditional methods, as widely described, in general, by Witold Kula (see W. Kula, Problemi e metodi di storia economica, Milano: Cisalpino-Goliardica, 1972, ed. orig. Problemy $i$ metody historii gospodarczej, Warszawa: 1963), are now undergoing a necessary work to verify and update. As has been highlighted by Ralph W. Hidy: «Business history has come a long way in the near half-century since that slow start; the small stream of publications has become a veritable flood of books and articles of varying quality, content, and approach. Despite the great mass of available material, there are still significant gaps in subject matter and methodology, and coming to grips with them will keep historians of business occupied for many decades to come» (R. W. Hidy, Business History: Present Status and Future Needs, in "Business History Review", Vol. 44, No. 4, 1970, $<$ http://www.jstor.org/pss/3112670 >).

\section{The new methodologies for research and telematics network}

The advent of the "information society", has to be considered in all its aspects, not only focused on changing traditional economic paradigms, but also a profound rethinking of scientific, manufacturing and distribution of knowledge. As noted, the consequences for the economy and the company were not trivial: «The mid-Seventies brought about all kinds of changes that really put us in the heart of a Third Industrial Revolution. While the general environment presented elements of strong turbulence (oil shocks, monetary disorder), the period is also characterized by an increase of international economic exchanges in a competitive scenario ever more aggressive with a demand or style increasingly personalized. We can also add in a more educated labor force (including a more pronounced female presence) that was increasingly unwilling to put up with rigid hierarchical relationships. At the same time, a powerful push changing forms of enterprise was technological innovation which, in various branches greatly reduced the necessity for economies of scale. But, above all, the last years of the past century were characterized by exceptional progress in electronics and in telecommunications up to the rise of internet. On the one side, these technologies allowed a greater control of the workers and the productive processes. On the other side, they also permitted a pervasive diffusion of information throughout the company, rendering possible a large mobilization of resources for the design and organizational functions. In addition, they showed greater responsiveness to the market, with no precedent for timing and adhesion, and an ability to adapt quickly to particular 
requests. In this context a company whose organizational borders are more porous seemed to come out. The general structure had a tendency to de-verticalization and to flattening the hierarchy. We find a structure in which a special emphasis was put on creativity, learning, or valuing an exchange of knowledge. The potential of the informational web to find an adequate materialization on the economic side brought about the need to translate it into an analogous network organization, an horizontal structure in which processes such as decentralization and autonomy of the various units prevailed, but also where there was active coinvolvement of all the employees in the strategic global design so that the Chandlerian concept of organizational capabilities overcame, without reservations, the confines of management to be extended into all the various company components» (F. Amatori, Busines History: State of the Art and Controversies, cit., p. 23, $<$ http://www.raco.cat/index.php/HistoriaIndustrial/article/viewFile/142797/194366 $>$ ). Moreover, the change of a cultural background was further underlined, with the emergence of novel relations between the company and the consumers, and the displacement of the center of value creation out of the production process; indeed: «A dominant cultural interpretation is not given, it is constructed out of the activities of firms interacting with customers. Firms and customers jointly construct meaning, each dependent on the other, each potentially in conflict with the other. The balance of power between the two sides may be roughly even--that is, firms cannot totally dominate but are also not simply passive recipients of consumer instructions. Firms too bring their skills--expressed in research, design, marketing and advertising--to the theater of consumption. They are part of the process of creating the values that underlie consumer decisions» (K. Lipartito, Culture and the Practice of Business History, in "Business and Economic History", Vol. 24, No. 2, 1995, p. 9, $<$ http://www.thebhc.org/publications/BEHprint/v024n2/p0001-p0042.pdf $>, \quad<$ http://www.hnet.org/ business/bhcweb/publications/BEHprint/v024n2/p0001-p0042.pdf $>$ ).

In the new context, the specific sectors with high added value of knowledge and with codified methodologies, as those related to economic-historical research, could not remain inert, lolling in a situation of unlikely immutability of established and reliable systems. The introduction and use of electronic sources among the tools of the craft of the business historians, in particular, already represents a first step towards a larger awareness (see A. Lepore, Archivi, fonti elettroniche e business history: l'avvio di una ricerca, in "Archivi \& Computer", No. 2, XVI, 2006, $<$ http://www.titivillus.it/periodico.php?id=15>; A. Lepore, La storia d'impresa in Italia e le nuove frontiere digitali: archivi e risorse telematiche, in "Culture e impresa", No. 5, 2007, $<$ http://www.cultureimpresa.it/05-2007/index.html $>$ ). Today it is difficult to find a scholar who is not prepared for a use, though limited, of the necessary tools, even the most elementary, to write text, to prepare a presentation, to do a literature search, to send and receive documents or other information with the computer and through the network. However, it should be considered a backdrop, if you intend to move from the practice, now inevitable, of the use of these technologies, to the more structured methodological innovation and, therefore, the placement of new media operating within a conceptual approach defined and clear rules. The electronic and telematics sources, with particular reference to the Internet, enable the scientific community to provide new resources for enrichment and extension of its purposes. This is not a simple substitution effect of old tools, but an extraordinary help to advance further on a field such as Business History.

The appearance of the web on the stage of scientific activity, studies and research marked the opening of a completely new phase for Business History. The use of electronic sources, in fact, requires an original methodology and a theoretical approach of specialized type, in order to offer appropriate solutions to the questions posed by the phenomenal development of the network, its segmentation and its practical applications, involving an activity of selection, evaluation, interpretation and exegesis of the documentation and digital resources, unique. This need arises, especially in reference to the role played by Internet for the primary sources, starting from the archives. Moreover, to the traditional sources, mainly represented by the business archives, now it is added multiple resources, from very different characteristics, which contribute to a profound renewal and substantial expansion of the potentiality of the discipline (see A. Lepore, Le fonti elettroniche per gli archivi e la storia d'impresa in Italia, in Archivi d'impresa. Stato dell'arte e controversie, edited by I. Lopane, Bari: 2009, 
$<$ http://www.icsim.it/nuovo\%20sito/area\%20convegni_prentazionelibri_premi/archivio_convegnistica 2007 1996/archivio2006/archivi impresa spoleto1 1nov.htm>). It is difficult to argue that the sources called "digital" are originally autonomous, i.e., capable of providing for themselves a full instrumentation for scholars and researchers of the field. However, the spread of these new media has been particularly intense, as to foreshadow more extensive statement of the innovative logic connected to them. Indeed, telematics and electronic sources have become increasingly independent identity, precisely through the peculiarities of the instrument with which they can be reached. On the Internet, all forms of documentation are virtual replicas of the originals; the same databases are developed on an intangible support, that goes far beyond simple hardware of a computer system. The network is at the same time, container and content, tool and resource, flow and structure: in this way, however, is not one of the major distinctions made by Kula, that among the factors "that create sources" and factors "that keep the sources" (W. Kula, Problemi e metodi di storia economica, cit., p. 90). These concepts become familiar with using increasingly aware of the potential offered by new methodologies. Hypertext, in particular, is the principal element introduced by the Internet, which, thus, assumed the value of a "conceptual network": it is an entirely new source, which can fully realize the opinion of scholars, that, in the second half of the nineteenth century, historical research was not based solely on written or printed documentation.

With the advent of computer technology and telematics, in addition, the assessment that the historian distinguishes its commitment in two different stages of reading sources and writing text has become scarcely convincing. The methodology to perform a search on the net - in particular, for Business History - differs from the traditional one, based on the use of a technique of sequential analysis of the sources. Edward Hallett Carr, in his 1961 work (see E. H. Carr, Sei lezioni sulla storia, Torino: Einaudi, 1966, ed. orig. What is history?, London: Macmillan \& Co. Ltd., 1961, $<$ http://www.palgrave.com/products/title.aspx?is $=0333977017>$,

$<$ http://www.history.ac.uk/ihr/Focus/Whatishistory/carr1.html>) , already described a method very similar to what would, then, prevailed in the normal practice of computer and telematics sources: «Laymen - that is to say, non-academic friends or friends from other academic disciplines sometimes ask me how the historian goes to work when he writes history. The commonest assumption appears to be that the historian divides his work into two sharply distinguishable phases or periods. First, he spends a long preliminary period reading his source and filling his notebooks with facts: then, when this is over, he puts away his sources, takes out his notebooks, and writes his book from beginning to end. This is to me an unconvincing and unplausible picture. For myself, as soon as I have got going on a few of what I take to be the capital sources, the itch becomes too strong and I begin to write - not necessarily at the beginning, but somewhere, anywhere. Thereafter, reading and writing go on simultaneously. The writing is added to, subtracted from, re-shaped, cancelled, as I go on reading. The reading is guided and directed and made fruitful by the writing: the more I write, the more I know what I am looking for, the better I understand the significance and relevance of what I find. Some historians probably do all this preliminary writing in their head without using pen, paper, or typewriter, just as some people play chess in their heads without recourse to board and chess-men: this is a talent which I envy, but cannot emulate. But I am convinced that, for any historian worth the name, the two processes of what economists call "input" and "output" go on simultaneously and are, in practice, parts of a single process. If you try to separate them, or to give one priority over the other, you fall into one of two heresies. Either you write scissors-and-paste history without meaning or significance; or you write propaganda or historical fiction, and merely use facts of the past to embroider a kind of writing which has nothing to do with history» (Edward Hallett Carr / The Historian and His Facts, <http://www.cooperativeindividualism.org/carr-edward historians-andtheir-facts.html >).

Indeed, the peculiar methodology of research focusing on electronic resources - given the nature of hypertext, based on a combination of written texts, sound sources, still and moving images is very similar to the historical process described by Carr and cannot be set as sequential analysis, but must have recourse to the mechanism of connection between different sources, through the links. In this way, you can also provide an order to the web browsing, which lets you select web sites and useful resources, as distinct from those unsuitable for scientific investigation or not addressed to a 
specific theme. The widespread adoption of the multimedia, of the technology of record linkage, of any other tool for collecting and processing complex of heterogeneous resources, can effectively and significantly expand the capabilities of those who make Business History, according to the criterion of the continuous flow of informations and of the connection between them of the various testimonies, no longer proceed in the direction of the linear development of a text, typical of traditional methods. These innovative techniques are, then - far from having completely replaced - a completion and improvement of the traditional sources, in addition, they favor, of course, an openness to new and wider experience of study and research, especially on the comparative side and on global scale.

One problem, not always similar to that faced by the documentation in paper form, is given by the digital memory storage (see T. Menzani, Chi conserva e cosa conservare per la storia d'impresa, <http://www.fondazionetelecomitalia.it/doc/programma/Menzani.pdf $>$ ). In fact, together with the need to preserve the electronic sources from the wear of time and from the technological obsolescence, the dynamics of a high-born mortality of websites is definitely one of the topics in order to claim a more permanent Internet, also in the field of Business History. Another key issue is the fact that, with telematics sources, there was a real "jump" from an incomplete documentation, to an excessive documentation. The risk inherent in the limitless multiplication of virtual sources, is the contemporary lack of an adequate system of controls and a system of scientific validation. If faced with inadequate documentation, the task of the historian (economic and non-economic) was to sharpen the wits, approaching his work "to that of the detective", as claimed by Carlo Maria Cipolla (see C. M. Cipolla, Tra due culture. Introduzione alla storia economica, Bologna: il Mulino, 1988), faced with an overabundance of "data", his task is no longer that of an investigation, but a selection. The virtual "detective" has no more need for raw material, the "clay" to build his investigation, but must acquire skills and tools necessary to distinguish the useful traces from the ones misleading and unnecessary. The aim of those who tend to avoid the progressive deskilling of sources, a damaging inflation of documentary resources valueless, is based on the choice of a methodology for the selection of the documents and on the search for new quality requirements for the sources on the net, as evidenced by the intense literature developed on the subject in recent years.

In any case, the extremely important contribution, in many ways remarkable, given by the new methods should not be confused, for any reason, with the need to maintain a high character of the contents, not to withdraw from the results achieved so far in terms of scientific quality and recognized autonomy of the discipline. From this point of view, as noted Luigi Cossa, over a century ago, it's not possible to exchange «the absolute truths of science with the assumptions of art», reducing «the first to a simple philosophy of economic history» (L. Cossa, Primi elementi di economia politica, Milano: Hoepli, $9^{\text {a }}$ ed., 1891, p. 25). Or as noted, at the beginning of the twentieth century, Augusto Graziani: "We must not confuse the truth of science with the rules of art and with the task of economic history» (A. Graziani, Institutions of Economics, Torino: Bocca, 1904, p. 19). If these considerations are still valid, then, it is fully justified - not only for reasons of timeliness - the use of new techniques and technologies, such as Internet. It is therefore understandable the transition to a more careful assessment of the value of these new methodologies, able to provide numerous opportunities for upgrading and extending the borders of the business historians. In fact, the telematic network and the digital media, in general, can make a contribution, both research and teaching activities, offering a set of tools, textures and materials of great significance for the discipline.

\section{The open innovation, the new markets of the "long tail" and the Business History}

The open innovation, according to the term coined by Henry Chesbrough (see $\mathrm{H}$. Chesbrough, Open. Modelli di business per l'innovazione, Milano, Egea: 2008, ed. orig. Open Business Models: How to Thrive in The New Innovation Landscape, Boston (MA): Harvard Business School Press, 2006, <http://www.openinnovation.net/Book/OpenBusinessModels/>; H. Chesbrough, Open Innovation: The new Imperative for Creating and Profiting from Technology, Boston (MA): Harvard Business School Press, 2003, <http://www.openinnovation.net/Book/NewImperative/>; Open Innovation, $<\underline{\mathrm{http}}: / / \mathrm{www} .0$ peninnovation.net $>$ ) to indicate the most recent model of industrial 
innovation, is nothing but the paradigm linked to the advent of a completely original form of dissemination and knowledge management globally, using Internet. It has been opened, in fact, a vast field of action, which, thanks to information and communication revolution promoted by the development of the telematic network over the past two decades, may allow participation in a broad scientific expertise - and not only - to help solve major problems for process innovation and product, as well as the affirmation of a new way of viewing the acquisition of knowledge, its control and management. As stated in a meticulous definition: «The Open Innovation paradigm can be understood as the antithesis of the traditional vertical integration model where internal research and development (R\&D) activities lead to internally developed products that are then distributed by the firm. If pressed to express its definition in a single sentente, Open Innovation is the use of purposive inflows and outflows of knowledge to accelerate internal innovation, and expand the markets for external use of innovation, respectively. Open Innovation is a paradigm that assumes that firms can and should use external ideas as well as internal ideas, and internal and external paths to market, as they look to advance their technology. Open Innovation processes combine internal and external ideas into architectures and systems. They utilize business models to define the requirements for these architectures and systems. The business model utilizes both external and internal ideas to create value, while defining internal mechanisms to claim some portion of that value. Open Innovation assumes that internal ideas can also be taken to market through external channels, outside the current businesses of the firm, to generate additional value. The Open Innovation paradigm treats R\&D as an open system. Open Innovation suggests that valuable ideas can come from inside or outside the company and can go to market from inside or outside the company as well. This approach places external ideas and external paths to market on the same level of importance as that reserved for internal ideas and paths to market in the earlier era) (H. Chesbrough, Open innovation: researching a new paradigm, New York-Oxford (NY): Oxford University Press, 2006, p. 1, $<$ http://books.google.it/books?hl=it\&lr=\&id=wBmA ft 5lgC\&oi=fnd\&pg=PA1\&ots=wp8DJMoD48 \&sig=D1 socM0QKdcbXUENs2f8nH6-8iw\#v=onepage\&q\&f=false $>$ ).

The method of crowdsourcing - an expression conceived and popularized by Jeff Howe in 2006 (see J. Howe, The Rise of Crowdsourcing, in "Wired", No. 14.06, 2006, $<$ http://www.wired.com/wired/archive/14.06/crowds.html >; Crowdsourcing: A Definition, $<$ http://crowdsourcing.typepad.com/cs/2006/06/crowdsourcing_a.html >; J. Howe, Crowdsourcing. Il valore partecipativo della folla come risorsa per il futuro del lavoro, Roma: Luca Sossella editore, 2010, ed. orig. Crowdsourcing: Why the Power of the Crowd Is Driving the Future of Business, New York (NY): Random House Inc., 2009, $<$ http://www.randomhouse.com/catalog/display.pperl?isbn=9780307396204>) - materializes, according to the guideline contained in Wired magazine: «When a company asks a vague community to play on his behalf a task first entrusted to its employees» (see cfr. R. Staglianò, Le aziende $e i$ creativi low cost migliaia di collaboratori via web, in "la Repubblica", July 17, 2006, $<$ http://www.repubblica.it/2006/07/sezioni/scienza_e tecnologia/creativi-low-cost/creativi-lowcost/creativi-low-cost.html>; Chainworkers 3.0/L'era del prosumer: come le aziende sfruttano le idee dei loro clienti, <http:/www.chainworkers.org/node/455 $>$ ). This is a new form of collaborative research, which allows a multitude of people and organizations, with knowledge and creativity, to contribute to the advancement of knowledge at all unusual, in the global economy. The "prototype" of this innovation is represented by Wikinomics (see Wikinomics, <http://www.wikinomics.com/blog/>), the blog inspired by the eponymous book of Don Tapscott and Anthony D. Williams (see D. Tapscott, A. D. Williams, Wikinomics. La collaborazione di massa che sta cambiando il mondo, Milano: Etas, 2007, ed. orig. Wikinomics: How Mass Collaboration Changes Everything, New York (NY): Portfolio, 2006, <http://www.wikinomics.com/book/>). According to that, made in both digital and paper format as a huge work in progress, the spread of mass collaboration (or peer production) - as some businesses did pioneers in the early years of the twenty-first century, soon imitated by a growing number of activities - is an opportunity of extraordinary importance, because it allows a unique form of participation in building innovative knowledge in different fields and is, at the same time, the metaphor of a new way of understanding economy and business system.

Through these procedures, particularly with the use of the open innovation and the crowdsourcing, it was possible not only to improve the standard and scope of corporate business initiatives, as such, but also use a tool offered by the network, to split into smaller common tasks 
major activities concentrated and to create new value, moving the center of gravity outside the company, without having to resort to the traditional activities of the offices of research and development (R \& D). Furthermore, in a broader sense, this innovative method was used to optimize, in many areas, the process of cognitive and scientific elaboration, its contents of merit and its objectives: thus, they could significantly reduce costs and time needed for achieving the related results and also enable institutions, groups, organizations and individuals to meet their own needs of knowledge advancement, problem solving and participation in a new stadium of the increased complexity of knowledge and its practical applications. Briefly, as indicated by Chesbrough: «Open Innovation means that companies should make greater use of external ideas and technologies in their own business, while letting their unused ideas be used by other companies. This requires each company to open up its business model to let more external ideas and technology flow in from the outside and let more internal knowledge flow to the outside. With a more open business model, Open Innovation offers the prospect of lower costs for innovation, faster times to market, and the chance to share risks with others (...). To thrive in this era, companies have to adapt business models to make them more open to external ideas and and paths to market. Those that effectively bring ideas from the "outside in" will tap into tremendous potential for identifying and creating new value; likewise, companies that move ideas from the "inside out", enabling others to use unused ideas, will realize a new way to capture more value and sustain themselves in these times of increasingly global markets and competition» (H. Chesbrough, Open Business Models: How to Thrive in The New Innovation Landscape, cit., pp. XIII-XIV). The new methodology, while representing a field of analysis and application of a completely new system on the evolution of business, is also an opportunity to upgrade technical research in fields of study, such as Business, which, in this way, can achieve a further instrumentation and establish connections, previously unimaginable, with a boundless area of expertise, through the electronic network. In any case, given the broad scope of the medium and the various conceivable alternatives for its use, we need a clear definition of the action areas of science, criteria and rules of use, forms of validation of the activities. 


\section{Figure 3-4. Open Innovation \& Closed Innovation: paradigms compared}

«Chesbrough describes the transition from the traditional internally focused "closed" innovation paradigm to an "open" innovation paradigm. His central thesis is that the closed innovation paradigm is now being rendered obsolete, primarily due to the growing mobility of skilled workers and the increased availability of Venture Capital (...). The figure below shows the knowledge landscape in the open innovation paradigm and summarizes, the key drivers of change (i.e. the factors eroding the closed innovation paradigm), as well as the contrasting principles of closed and open innovation. Whereas the closed paradigm is characterized by stage gate process to drive projects from internal research to internal development and market launch (typically represented as a funnel where only the best ideas pass through), various other options are utilized in the open innovation model, such as the spin-out of technology that does not fit the business model of the company, the licensing-out of IP to other companies to strengthen the value system, the licensing-in of best-of-breed IP of third parties and the acquisition of advanced technology companies to advance their own business model» (Caneval-Models on the dynamics of innovation - "Open innovation, The new imperative for creating and profiting from technology", by Henry Chesbrough, $<\underline{\text { http://www.caneval.com/vision/innovation/innovation2.html }>\text { ). }}$

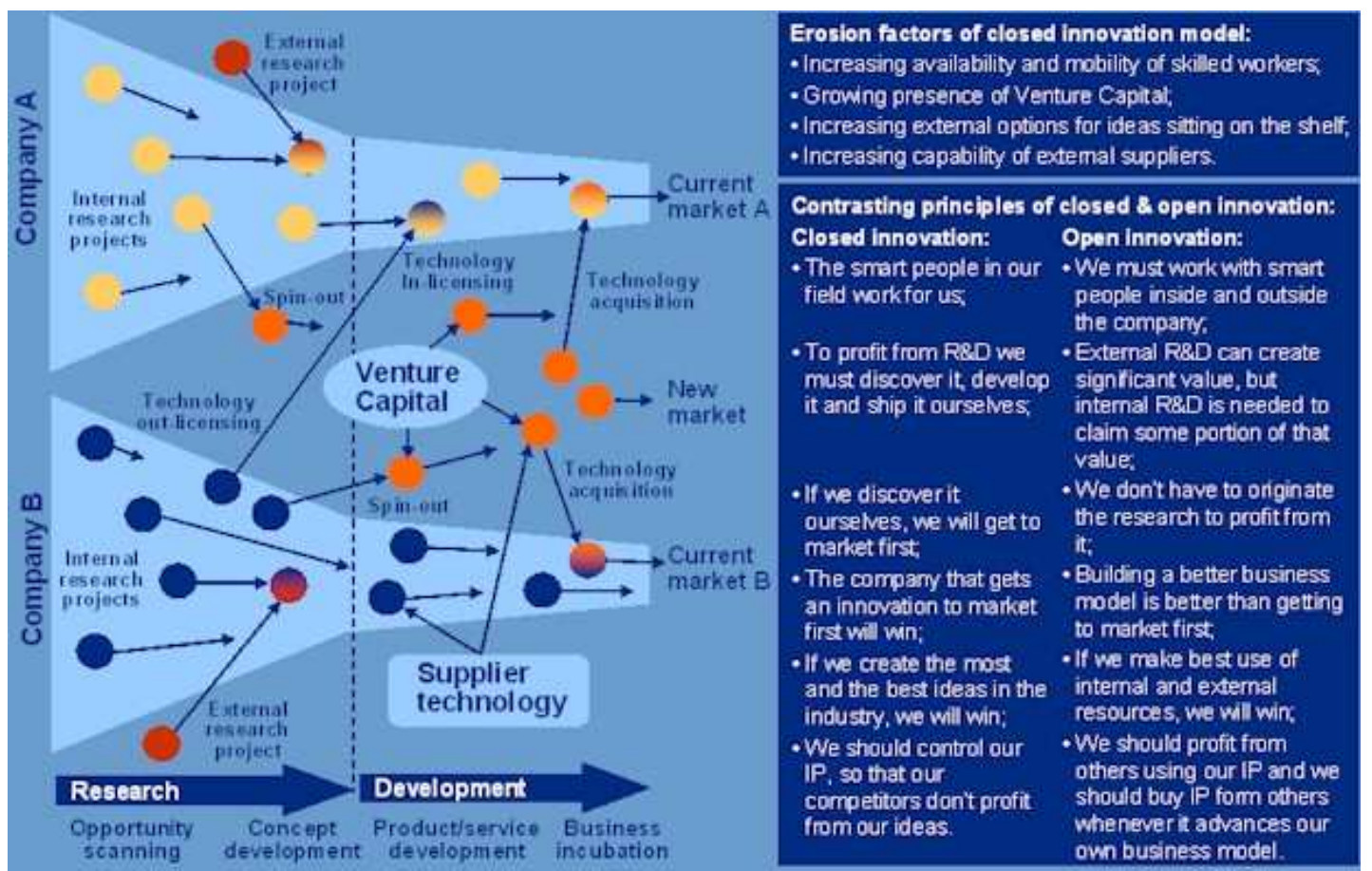

Source: Caneval-Models on the dynamics of innovation - "Open innovation, The new imperative for creating and profiting from technology", Henry Chesbrough,

$<$ http://www.caneval.com/vision/innovation/innovation2.html $>$. 


\begin{tabular}{|l|l|l|l|}
\hline Closed Innovation & Mass Customization & Customer Co-Design & \multicolumn{1}{c|}{ Open Innovation } \\
\hline $\begin{array}{l}\text { Traditional mass } \\
\text { production and } \\
\text { process }\end{array}$ & $\begin{array}{l}\text { Flexible } \\
\text { manufacturing, } \\
\text { improvement, slow } \\
\text { customer feedback } \\
\text { cycle (e.g. according } \\
\text { to sales), customer } \\
\text { surveys, market } \\
\text { potential, variety of } \\
\text { products }\end{array}$ & $\begin{array}{l}\text { customizable / } \\
\text { changeable elements, } \\
\text { direct customer } \\
\text { interaction when } \\
\text { cefining the product, } \\
\text { solutions like } \\
\text { hanufacturing methods } \\
\text { can be predefined, } \\
\text { otherwise customers are } \\
\text { offered tools to design } \\
\text { products, customer } \\
\text { creative contribution } \\
\text { and high customer } \\
\text { participation }\end{array}$ & $\begin{array}{l}\text { Customer creative } \\
\text { contribution, design of } \\
\text { core solutions, no } \\
\text { ownership (or } \\
\text { customer ownership), } \\
\text { returns on } \\
\text { implementation and } \\
\text { attached services, } \\
\text { multiple stakeholders, } \\
\text { high customer } \\
\text { commitment }\end{array}$ \\
& & & \\
\hline
\end{tabular}

Source: From Closed Innovation to Open Innovation: IRIS Helsingor Denmark - Beyond Creativity,

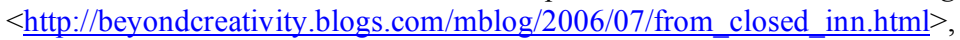

$<$ http://beyondcreativity.blogs.com/photos/uncategorized/makipaaahonenmantymakiiris 1.png $>$.

There are two theoretical points of reference, from which you can start, for a deeper understanding and appreciation of this path. The first is the volume published by Chris Anderson on The long tail, of great interest, because - in addition to a method of investigation and study, very similar to those involved in Economic History, i.e., the quantitative and serial analysis of the economic phenomena, which, starting from concrete facts, reaches the theoretical definition and, then, haul in the reality - it has actually given an interpretation of the transition from the old market and mass production, to a system in which niche markets, when combined, combined together, may represent a significant alternative to the previous system (see C. Anderson, La coda lunga. Da un mercato di massa a una massa di mercati, Torino: Codice Edizioni, 2007, ed. orig. The Long Tail: Why the Future of Business is Selling Less of More, New York (NY): Hyperion, 2006; C. Anderson, The Long Tail, in "Wired", No. 12.10, 2004, <http://www.wired.com/wired/archive/12.10/tail.html >; The Long Tail. Chris Anderson's blog, <http://www.longtail.com/ $<$ http://longtail.typepad.com/the long tail $>$ ). The second reference is in Coimbatore Krishnarao Prahalad and his most famous work (see C. K. Prahalad, La fortuna alla base della piramide. Sconfiggere la povertà e realizzare profitti, Bologna: il Mulino, 2007, ed. orig. The Fortune at the Bottom of the Pyramid: Eradicating Poverty Through Profits, Upper Saddle River (NJ): Wharton School Publishing, 2005, <http://www.whartonsp.com/store/product.aspx?isbn=0131467506>), who analyzed the distribution income through a pyramid, whose base, above, was seen as a blur, a part of the world population need only to social work interventions. Not considered in the uniqueness of individuals, but in all its extension, representing a crucial slice of the world population with very low incomes - have examined the 4 billion people with an income below two dollars per day -, the base of the pyramid takes on another meaning. This significant proportion of the population, in fact, may constitute a huge market. Based on this simple but not obvious assessment, has given rise to a range of strategies and actions - especially by a group of private companies and some multinational wise - that, somehow, have replaced the old welfare policies. Just think what it has meant microcredit internationally or look at some of the initiatives of considerable importance that some companies have designed for the most backward countries of the world, with the creation of single product or, in part, self, capable of satisfy a large and fragmented demand.

Considering the opportunities provided by these innovative guidelines, there is the possibility of identifying a route entirely new, very useful for Business History. Moreover, the path of Business History has been crossed several times, with the outright innovation - and thus, today, even with that of open innovation, which is an expansion of the horizons of other forms of innovation (of product, of process, organizational) and is not limited to the implementation of new technologies - is demonstrated by the following overview on the history of innovation. 


\section{Figure 5. History of Innovation}

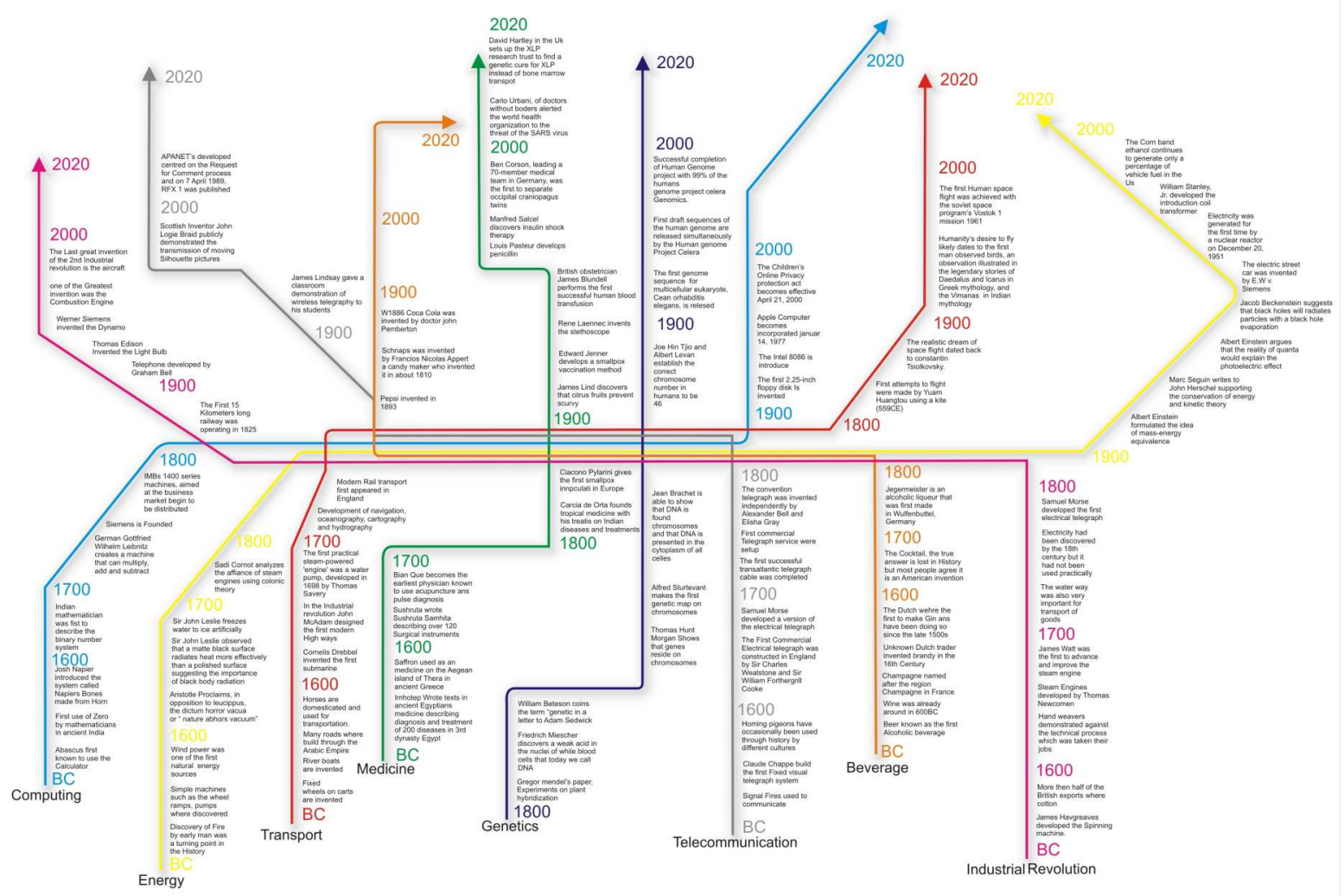

\section{Systemic History of Innovation Logle}

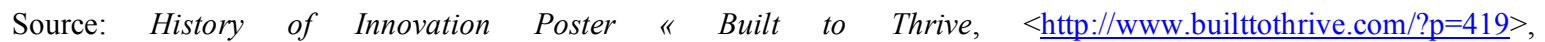
$<$ http://www.builttothrive.com/wp-content/uploads/2009/10/HistoryOfInnovation.jpg>. In this site is written that: «We have been trying to find different ways to depict the history of innovation (this is a draft version and work-in-progress). The posted does not show any "time bands" of change nor does it provide any detail as to the inventor. The idea is to represent some of the major changes from the industrial revolution onwards that changed our lives»».

From the definition of globalization which was coined by Theodore Levitt - «the emergence of global markets for standardized consumer products on a previously unimagined scale of magnitude» (T. Levitt, The Globalization of Markets, in "Harvard Business Review", Vol. 61, No. 3, 1983, <http://www.vuw.ac.nz/ caplabtb/m302w07/levitt.pdf $>, \quad<\underline{\text { http://hbr.org/1983/05/the- }}$ globalization-of-markets/ar/1>) -, to the emergence of new theories related to overcoming trend of the mass market, through the dissemination of a niche "mass of markets", it seems a lot of water has passed under the bridge, yet it is only a few years, less a quarter of a century. The diffusion of the model of the so-called "long tail", i.e., a tool that can provide a new interpretative key for understanding the transition from Fordist society to the "post-industrial", represents a significant opportunity to examine the phenomenon of the enterprise evolution, using the latest sources and can provide an overview, as the electronics. Indeed, according to Nicholas Carr: «If the electric dynamo was the machine that fashioned twentieth century society - that made us who we are - the information dynamo is the machine that will fashion the new society of the twenty-first century» (Nicholas Carr, $\mathrm{Il}$ lato oscuro della rete. Libertà, sicurezza, privacy, Milano: Etas - Rizzoli, 2008, ed. orig. The big switch: rewiring the world, from Edison to Google, New York (NY): W. W. Norton \& Co., 2008, p. $21,<$ http://www.nicholasgcarr.com/bigswitch/>). In any case, the path is traced and it is reasonable to initiate new elaborations, able to pick the records, materials, databases and knowledge spread, that, 
thanks to the telematic network and an updated survey methodology, can be fully put to good use, opening new perspectives of study for many different themes of Business History, a discipline came from afar, but very current and intended to draw a not short future.

Finally, you can groped an overall assessment, by reference to a reflection which can outline the role of today's Business History - came, now, to be an autonomous field of research and one of the major fields of economics and management sciences - but also its future less close: «I would like to remember that the well-known Italian economic historian, Carlo Cipolla, at the end of a very productive career as a scholar decided to leave us a precious book of methodology in which-to characterize his field - he used the expression "between two cultures", meaning that economic history was in between two very important areas of study (economics and history). If it is possible, business history is an even more complicated plight since here the cultures are THREE! In addition to the two mentioned by Cipolla, we add managerial sciences. It is also a sort of practical matter because for us it means deciding which academic alliance and so location we are going to choose. Are we going to favor the department of economics or a management department or a department of humanities? (...) In an ideal world, certainly the best would be to be fully in command of the three cultures (economics, managerial studies, and history) and capable of moving without friction between a department of economics and that of management or humanities. I am afraid that for my generation, probably very, very few scholars are able to do this (...) but we must indicate this way to our younger colleagues from whom we should pretend lots of hard work based on reading tons of literature and searching many archives. But we will also need to concede the most ample freedom to single out objectives and methods of research, remembering always that business history has a crucial role in comprehending the major changes of our epoch» (F. Amatori, Busines History: State of the Art and Controversies, $\begin{array}{lllll}\text { cit., } & \text { p. } & 27 & \text { e } & \text { p. }\end{array}$ $<$ http://www.raco.cat/index.php/HistoriaIndustrial/article/viewFile/142797/194366 $>$ ). Based on these considerations, therefore, we can draw a new map of the tasks of Business History, which, with increasing acquisition and mastery of new technology tools and innovative methods of research, is able to expand its sphere influence towards new spaces within the disciplines of science and to play a leading role in identifying the fundamental characteristics of the transition from Fordism to postFordism, from the society of mass production to the production customized and the niche markets: in this way, not only the past will become clearer, but will be more clearly delineated sections, problems and prospects of a core economy of the third millennium. 